HUNGARIAN AGRICULTURAL ENGINEERING

$N^{\circ} 27 / 2015$ 24-26

Published online: http://hae-journals.org/

HU ISSN 0864-7410 (Print) / HU ISSN 2415-9751(Online)

DOI: 10.17676/HAE.2015.27.24
PERIODICAL OF THE COMITTEE OF AGRICULTURAL AND BIOSYSTEM

ENGINEERING OF

THE HUNGARIAN ACADEMY OF SCIENCES

and

SZENT ISTVÁN UNIVERSITY

Faculty of Mechanical Engineering

\title{
EXAMINATION OF VELOCITY DEPENDENT FRICTION OF STEEL PROBES
}

Author(s):

A. Csatár ${ }^{1}-A$. Varga ${ }^{2}$

Affiliation:

${ }^{1}$ Montavid Thermodynamic Research Group

${ }^{2}$ Szent István University, Faculty of Mechanical Engineering, Department of Mechanics and Technical Drawing

Email address:

csatar.attila@gek.szie.hu, varga.attila@gmgi.hu

\begin{abstract}
The phenomenon of friction reduces the efficiency of almost all machines in practice. For reduce the deficits we have to understand this phenomenon and we have to take it in all cases into consideration during design. Nevertheless in certain cases the descryption of a friction process is very difficult; because this depends on a lot of parameters. In case of polymers, granular materials or in geology the rate- and state dependent friction have great importance. In this paper velocity dependent friction of steel is examined with the help of a direct shear apparatus, which was developed in our earlier work.
\end{abstract}

\section{Keywords}

direct shear test, friction, time-dependent, velocity-dependence

\section{Introduction}

The friction is the resistance to relative motion between two or more substances. The relative motion can be created between masses of fluids, gases, solids, or combinations thereof. Since the friction and the effects of friction are so evident, the physicists have searched the fundamental causes of friction for thousands of years [1].

The phenomenon of friction reduces efficiency of the machines in practice. In order to reduce losses, we have to examine and understand this phenomenon. Friction cannot be neglected for the major part of mechanical engineering.
Coulomb was the first researcher, who examined the friction process about three centuries ago and he discovered that the kinetic friction does not depend on the shear velocity [2]. Later further researches showed that this phenomenon depends on several parameters, such as type of material, roughness, temperature. It is remarkable also, that friction may be velocity dependent. In some cases, due to the wide variety of parameters the description of a friction process is very difficult. In geology, mining- and earthquake science, in case of polymers, granular materials or other special materials the rate- and state-dependent friction (creep and relaxation) have great importance. Friction is a form of energy dissipation, therefore it is the subject of thermodynamics. However, only few researchers investigate the thermodynamic aspects of time dependent of friction $[3,4,5]$. The aim of our work was to examine velocity dependent properties of friction in case of steel with our previously developed direct shear testing apparatus. This shear apparatus is connected to the INSTRON 5581 type universal material testing machine and it is suitable for shearing with different (in certain cases very low) velocities and on different normal loads.

\section{Velocity dependent experiments}

The purpose of the multiple-velocity tests was to look for variations of shear strength as a function of velocity. A step increase of shear velocity results an immediate jump in frictional coefficient followed by displacement dependent decay and stabilization at a new steady-state friction. The reverse is seen if the shear speed is decreased (Figure 1.).

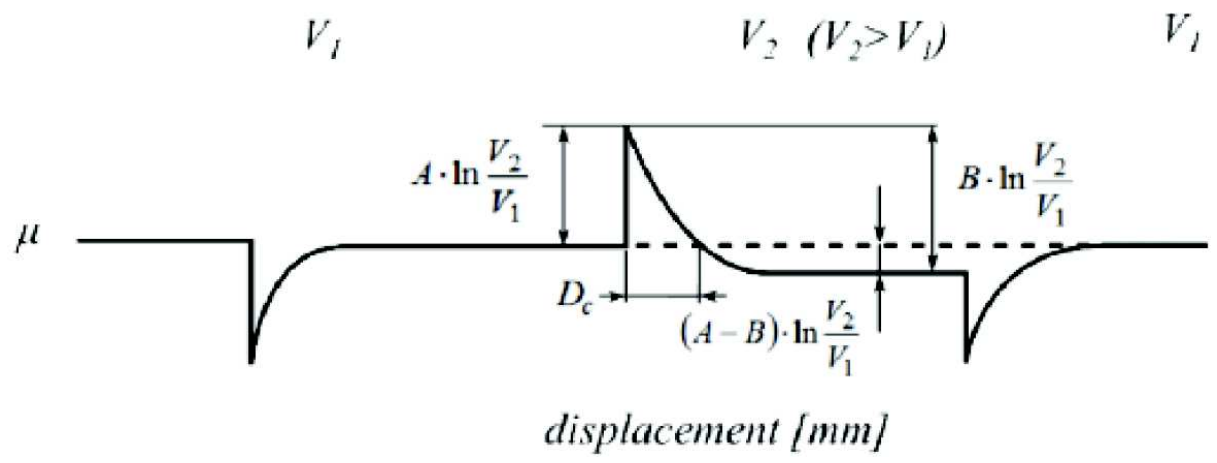

Figure 1. Effect of steps in shear speed on a friction coefficient 
Dietrich and Kilgore [6] formulated an empirical law for fault tests. This formulation provides a descriptive framework for the interpretation of the transient shearing phenomenon. The coefficient of friction can be represented.

$$
\mu=\frac{\tau}{\sigma}=\mu_{0}+A \cdot \ln \left(\frac{V}{V^{*}}+1\right)+B \cdot \ln \left(\frac{\Theta}{\Theta^{*}}+1\right)
$$

where $\tau$ and $\sigma$ are shear and normal stress $V$ is a shear speed and $\Theta$ is a state variable. Parameters , A and B are experimentally determined constants and $\mathrm{V}^{*}$ and $\Theta$ are normalizing constants [6]. A thermodynamic generalization of this empirical rate- and state-dependent friction law is given in [7]. In an ideal velocity stepping test, parameters A, B contain the graphical interpretation indicated in Figure 1 and $\mu 0$ represents the nominal coefficient of friction which for most materials ranges from 0.5 to 0.8 . In practice, it is not possible to instantaneously step to a new constant sliding speed because of finite apparatus stiffness. Apparatus stiffness effects are readily modelled and cause the rounding of friction peaks and oscillations that are visible in Figure 1. In case of rocks, the values of the coefficients A and B generally vary between 0.005 and 0.015 . [6]

\section{Experimental measurements}

The design was made on the basis of Dietrich's vertical shear apparatus [8]. In case of Dietrich's arrangement the displacement was vertical and the normal force was horizontal, still in our case the normal force is provided by an INSTRON 5581 type universal material testing machine, so it should be vertical thus the displacement should be horizontal. To keep the contact surface invariant during the shear process, one of the probes must be longer. We decided to use a box type layout because this apparatus must be suitable for shearing also granular materials, for this reason this must contain a fixed, loaded part and a moving part. These parts were suitable for fixing the probes. The shear force was measured by a load cell which is at the holding point of the fixed part; the displacement was measured by an inductive displacement transducer at the moving part. The displacement has been provided by a stepper motor (Figure 2.).

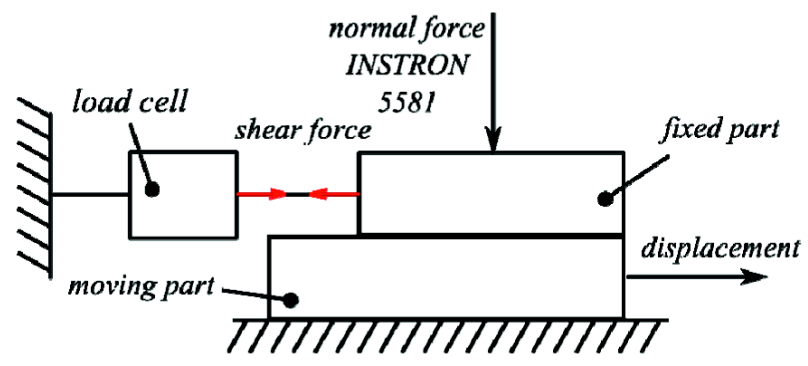

Figure 2. The sample assembly

To reduce the friction force between the moving part and the base-plate, linear bearings were used. Owing to the stepper motor and the control electronics very low shear velocity can be set. The rotation of the stepper motor is transformed to linear displacement by a screw shaft, this connects to the stepper motor with a cased coupling $[9,10]$.

\section{Results}

The usual experimental protocol for evaluating rate- and statedependent friction changes the shear velocity in a stepwise manner under of constant normal stress. Multiple velocity tests were carried out with constant shear velocity for a predetermined displacement, then suddenly changed to a different velocity and held constant for a while and changed back to the first velocity again. The tests were carried out with two different speed settings, $4,4-43,6$ and $10,1-79,1 \mu \mathrm{m} / \mathrm{s}$, for steel probes. Additionally the different normal stress level was $200 \mathrm{kPa}$. During the tests the shear force and the displacement were measured and the shear diagrams were determined. The purpose of these multiplevelocity tests was to look the time dependent friction coefficient as seen in the earlier rock friction experiments of Dietrich. In these earlier works two different velocity effects were observed, the step increase of shear velocity results in an immediate jump in frictional coefficient followed by displacement dependent decay and stabilization at a new steady-state friction. The reverse is seen if the shear speed is decreased. This friction coefficient jump on the higher speed level and the decrease on lower speed level can be seen on the shear diagrams (Figure 3.).
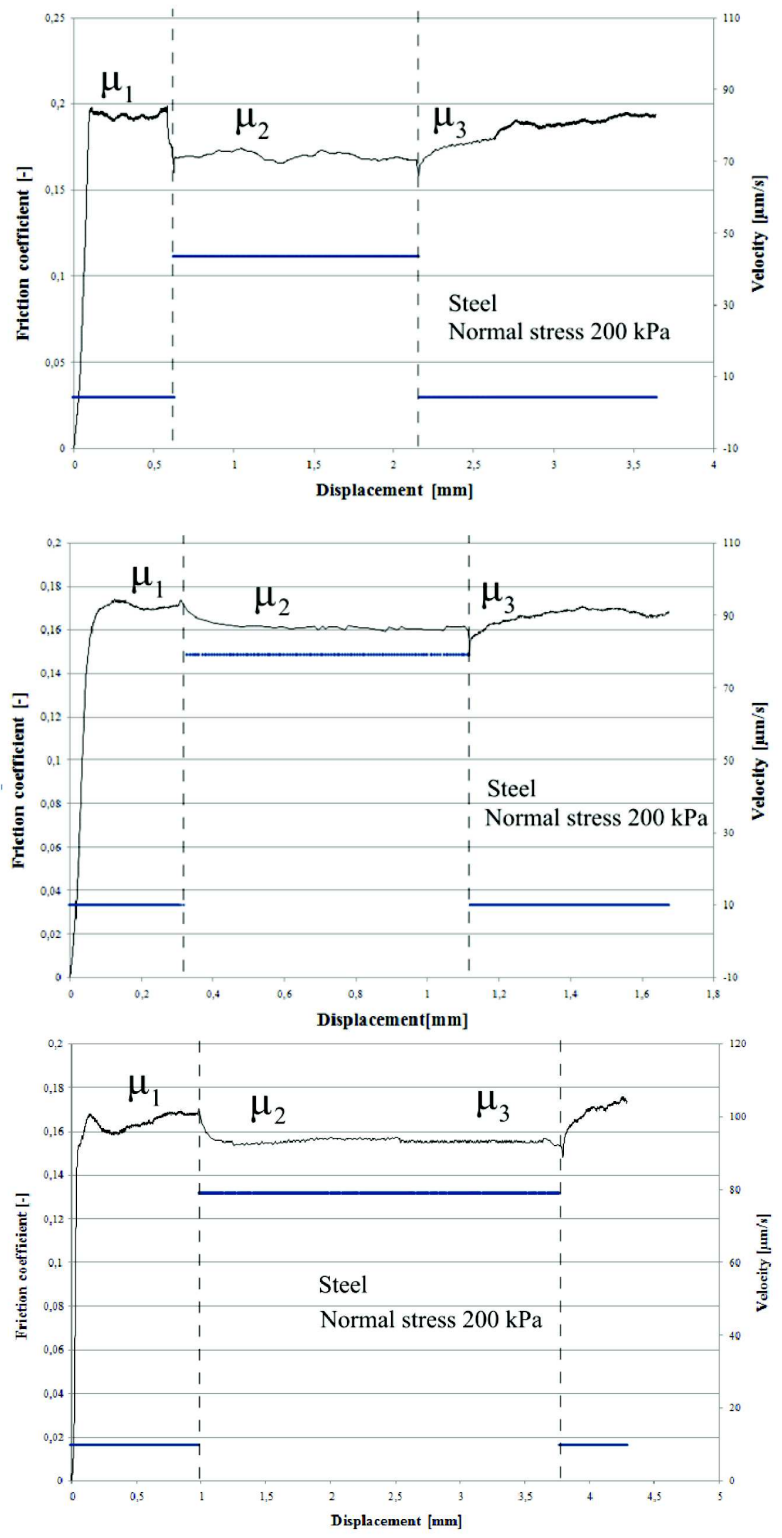

Figure 3. Displacement in function of time

Based on these diagrams and equation (1), the A and B parameters could be determined. The following table contains the results: 
Table 1. Testing results

\begin{tabular}{|l|l|l|l|l|}
\hline \multirow{2}{*}{ - } & \multicolumn{2}{|c|}{$4,4-43,6 \mu \mathrm{m} / \mathrm{s}$} & \multicolumn{2}{c|}{$10,1-79,1 \mu \mathrm{m} / \mathrm{s}$} \\
\cline { 2 - 5 } & 1 st test & 2nd test & 3rd test & 4th test \\
\hline A & 0,0045 & 0,0054 & 0,0013 & 0,0011 \\
\hline B & 0,0173 & 0,0184 & 0,0063 & 0,0043 \\
\hline
\end{tabular}

\section{Conclusion}

During our work, the measurements were carried out with two different velocity settings. Based on the results, this apparatus is suitable to examine rate- and state-dependent friction similar to the characteristics presented in the literature. We determined the constants which were needed to describe the phenomenon of friction in case of steel probes.

\section{References}

[1.] Dietrich J. H.: 1979. Modeling of Rock Friction I.: Experimental Results and Constitutive Equations, Journal of Geophysical Research, Vol. 84, pp. 2161-2168.

http://dx.doi.org/doi:10.1029/JB084iB05p02161

[2.] Dowson D.: 1979. History of tribology, Longman, New York [3.] Ruina A. L.: 1983. Slip Instability and State Variable Friction Laws, Journal of Geophysical Research, Vol. 88, pp. 10359-10370. http://dx.doi.org/doi:10.1029/JB088iB12p10359
[4.] Mitsui N., Ván P.: 2014. Thermodynamic aspects of rock friction, Acta Geodaetica et Geophysica, Vol. 49, pp.135-146. http://dx.doi.org/10.1007/s40328-014-0048-6

[5.] Ván P.: 2010. A képlékenység termodinamikája. In: Fülöp T.(szerk.) Idő és térderiváltak anyagtörvényekben. Mérnök geológia Közetmechanika Kiskönyvtár 10, Mủegyetemi Kiadó, Budapest, pp. 15-50.

[6.] Dietrich J. H., Kilgore, B. D.: 1994. Direct observation of frictional contacts: New insights for state-dependent properties, Pure and Applied Geophysics PAGEOPH, Vol. 143, pp. 283-302.

[7.] Ván P., Mitsui N., Hatano T.: 2015. Non-Equilibrium Thermodynamical Framework for Rate- and State-Dependent Friction, Periodica Polytechnica Civil Engineering, Online First paper 8249. http://dx.doi.org/doi:10.3311/PPci.8249

[8.] Dietrich, J. H.: 1981. Constitutive properties of faults with simulated gouge, Geophysical Monograph Series, Vol. 24, pp. 103-120. http://dx.doi.org/doi:10.1029/GM024p0103

[9.] Csatár A., Safranyik F., Bércesi G.: 2013. A NEW direct shear testing apparatus for the examination of the velocity- and timedependent friction, Hungarian Agricultural Engineering No 25; pp. 54-58; (ISSN 0864-7410)

[10.] Asszonyi, Cs., Kertész, P., Richter, R.: 1980. A kőzetmechanika anyagszerkezeti és reológiai alapjai, Veszprémi Akadémiai Bizottság, Veszprém, pp. 446. 